\title{
Exploratory Study on the Relationship between Entrepreneurial Attitude and Firm's Performance
}

\author{
Kum-Lung Choe ${ }^{1}$, Siat-Ching Loo ${ }^{1} \&$ Teck-Chai Lau $^{2}$ \\ ${ }^{1}$ Faculty of Business and Finance, Universiti Tunku Abdul Rahman, Kampar, Malaysia \\ ${ }^{2}$ Faculty of Accountancy and Management, Universiti Tunku Abdul Rahman, Bandar Sungai Long, Malaysia \\ Correspondence: Kum-Lung Choe, Faculty of Business and Finance, Universiti Tunku Abdul Rahman, Perak \\ Campus, Jalan Universiti, Bandar Barat, 31900, Kampar, Perak, Malaysia. Tel: 60-5-468-1313. E-mail: \\ choek1@utar.edu.my
}

Received: January 17, 2013 Accepted: February 28, 2013 Online Published: March 28, 2013

doi:10.5539/ass.v9n4p144 URL: http://dx.doi.org/10.5539/ass.v9n4p144

\begin{abstract}
There is an increased emphasis on entrepreneurship research around the globe. The Census of Establishments and Enterprises 2006 shows that $99.2 \%$ or 518,996 of business establishments in Malaysia were small and medium enterprises (SMEs). A critical question remains - what factors affect entrepreneurial performance? Not all business start-ups were successful and managed to survive into the future. This study aims to understand how entrepreneurial attitude affects the performance of SMEs in Malaysia. Self-administered questionnaires were distributed to owner managers and data were analyzed using regression model. Results show that all five dimensions of entrepreneurial attitude are positively related to firm performance.
\end{abstract}

Keywords: entrepreneurial attitude, small and medium enterprises, firm performance

\section{Introduction}

From a nation's standpoint, entrepreneurship is seen as a source of employment and innovation and this in turn contributes to the economic development of a nation. Even developed countries such as the United States of America recognizes the importance of entrepreneurship and declared February 24 to March 3, of 2007 as Entrepreneur Week. In general, entrepreneurship boosts the economic development of a nation by increasing per capita output and income of a territory. Since entrepreneurs promote enterprises or businesses, they infuse dynamism in economic activities within their territory (Linan, Rodriguez-Cohard \& Rueda-Cantuche, 2005). Recognizing the role of an entrepreneur as the primary catalyst for economic growth, the Malaysian government is attempting to encourage more individuals to take up the challenge of being an entrepreneur. The SME Annual Report 2006 reveals that SMEs accounted for $99.2 \%$ of total business establishments while the contribution of the SME sector to Malaysia's real gross domestic product was 32\% (Department of Statistics Malaysia, 2006). SMEs have also contributed significantly to employment, providing jobs for over 5.6 million workers and were accounted for $56 \%$ of total employment.

More and more researchers recognized the importance of attitudes in entrepreneurial research (Drucker, 1985; Gasse, 1985; Greenberger \& Sexton, 1987; Olson \& Bosserman, 1984). Robinson et al. (1991), in their study, found attitude a better approach to the description of entrepreneurs than either personality characteristics or demographics. Instruments measuring attitude were found to account for more variances in a particular set of behaviors as compared to instruments measuring personality or traits (Ajzen, 1982; Ajzen \& Madden, 1986; Epstein, 1984).

Not all business start-ups were successful and managed to survive into the future. This study aims to understand how entrepreneurial attitude affects the performance of SMEs in Malaysia. The result of this study can serve as a reference for relevant parties to better align their efforts in enhancing their entrepreneurial performance.

\section{Entrepreneurial Attitude}

Many studies have been conducted to determine the demographic and personality characteristics of entrepreneurs. Ajzen and Fishbein (2005) raised their concerns on many occasions where personality theories lost its effectiveness in measuring entrepreneurial attitudes. The limitations of studying demographic and personality characteristics of entrepreneurs are associated with the lack of predictive validity between groups of entrepreneur 
and non-entrepreneur (Huefner, Hunt \& Robinson, 1996). It means certain characteristics differed on a variety of characteristics which are supposed to be stable across time and situation according to personality theory. In order to correct the inadequacy of psychological models based on personality, entrepreneurship researchers switched their attentions to attitude model. Switching the emphasis from personality characteristics to entrepreneurial attitudes allows researchers to take into considerations both situation and individual when they examine entrepreneurial process (McCline, Bhat \& Baj, 2000).

Robinson et al. (1991) conclude in their study that attitude is presented as a better approach to the description of entrepreneurs than either personality characteristics or demographics. Subsequent empirical studies also confirm that attitudes can be predicted from beliefs and evaluations (Ajzen \& Fishbein, 2005). According to Robinson et al. (1991), entrepreneurial attitude can be explained by the tripartite model which examines attitude in three dimensions - affect, cognition, and behaviour. The cognitive component reflects the non-criterial beliefs and thoughts of a person toward an attitude. The affective component is associated with feelings about an object which involves values and emotions. The affective feelings will result in an individual evaluating his/her experiences in positive or negative ways which in turn prompt for positive or negative behaviors. Behavioral component refers to habitual behavior patterns derived from past behaviours as well as inclination and predisposition to act in a certain direction (Robinson et al., 1991).

Four constructs are found in the measurement of entrepreneurial attitude orientation - achievement, innovation, personal control, and self-esteem.

The first dimension, achievement, is an important determining factor in choosing entrepreneurship as a career. The individual desire for appreciation corresponds to the needed motivation for becoming a successful entrepreneur (McClelland, 1961). The individual that possesses this need is said to be inclined in exploratory efforts and be able to become a very successful entrepreneur (McClelland, 1961). This is the same characteristic as increase self-satisfaction, readiness in facing challenges, and the freedom in determining the amount of effort needed to succeed in the chosen field.

Self-esteem being the second dimension of entrepreneurial attitude refers to the respect for and good feelings about oneself. Self-esteem is a crucial dimension of entrepreneurial attitude because perceptions of others will influence an individual's self-esteem and subsequently one's behaviour (Strauss, 2005). Therefore, an individual's self-esteem in business reflects one's perceived competency and self-confidence in his or her entrepreneurial activities (Hogg \& Cooper, 2007). Individuals having strong confidence in their abilities skills are set to achieve success in a new venture because they are motivated to commit the necessary effort (Douglas \& Shepherd, 2000).

The third dimension is personal control. The construct was first developed by Rotter to explain the relationship between the perception of control an individual has over his/her life and the subsequent reward derived from that behaviour (Rotter, 1966). It is referring to an individual's attitude in handling one's daily affairs which in turn influences one's decisions and actions. In essence, personal control is one's belief in the ability to control his/her future. It is essential because it provides confidence, commitment, and determination which enable an individual to pursue his or her entrepreneurial journey (Din et al., 2005).

Innovation, the fourth dimension, is commonly viewed as the key to continuous entrepreneurship and has been presented as the main criterion for entrepreneur activity (Schumpeter, 1983). Innovation manifests the support of novel ideas and creative processes that are different from the current practices and technologies (Lumpkin \& Dess, 1996). Entrepreneurial individual is characterized principally by innovative behaviour (Carland et al., 1984). This behaviour in turn inspires entrepreneurs to be pioneers where they are willing to move away from the conventions and venture into uncharted waters. Innovation relates to activities such as developing new products and methods as well as finding new markets and creating new organizations. Consequently, innovation refers to the exclusive and unique ways of conceptualizing and implementing business ideas (Drucker 1985).

The study conducted by McCline, Bhat and Baj (2000) shows that the inclusion of opportunity recognition to the original EAO provides accurate and better discrimination between entrepreneurs and non-entrepreneurs. Opportunity recognition is perceived to be related to proactiveness and risk taking which are important components of the entrepreneurial process. In sum, opportunity recognition successfully measures the attitude toward entrepreneurial opportunity. Opportunity recognition fills in the gap between cognition and action (McCline, Bhat \& Baj, 2000).

Opportunity recognition is defined as identifying the potential for new profit through the founding and formation of a new business venture or significant enhancement of an existing venture (Christensen \& Peterson, 1990). Recognizing an entrepreneurial opportunity is not the same as knowing how to take advantage of the opportunity 
(Venkataraman, 1997). Therefore, entrepreneurs must have possessed something unique that enables them to gain business advantage in the midst of the change, chaos and confusion (Schumpeter, 1983).

\section{Hypotheses}

Review of existing literature has led to the development of the hypotheses in this research. The following are the hypotheses:

H1: There is a significant positive relationship between entrepreneurial attitude and firm performance.

H1a: There is a significant positive relationship between achievement and firm performance.

$\mathrm{H} 1 \mathrm{~b}$ : There is a significant positive relationship between self-esteem and firm performance.

H1c: There is a significant positive relationship between personal control and firm performance.

H1d:There is a significant positive relationship between innovation and firm performance.

H1e: There is a significant positive relationship between opportunity recognition and firm performance.

\section{Research Instruments}

In order to obtain reliable information from the respondents, established and validated scales are adapted in this research. The independent construct in this study is entrepreneurial attitude. The scale of entrepreneurial attitude orientation (EAO) was originally developed by Robinson et al., (1991). The EAO scale was developed based on the tripartite attitude model proposed by Allport (1935) and was validated by many studies (Huefner, Hunt \& Robinson, 1996; Lindsay, Jordaan \& Lindsay, 2005). The original scale comprises of four dimensions. The fifth dimension of opportunity recognition was added in this research to enhance the measurement of entrepreneurial attitude based on the work of McCline, Bhat and Baj (2000). A total of 81 items were found in the scale. Sample items are "I get my biggest thrills when my work is among the best there is" (Achievement), "I believe that to succeed in business it is important to get along with the people you work with" (Self-Esteem), "I know that social and economic conditions will not effect my success in business" (Personal Control), "I get excited when I am able to approach tasks in unusual ways" (Innovation), and "I usually can identify what my clients need to make their stay more helpful" (Opportunity Recognition).

The dependent construct, firm performance (FP), is measured using the scale developed by Delaney and Huselid (1996) which was first published in Academy of Management Journal in 1996. Objective or actual firm performance was not measured; instead, items on perceived performance were included in the scale. Perceived performance yields more merits as most owners of small and medium enterprises (SMEs) are reluctant to reveal their actual performance (Ward, Pearson \& Entrekin, 2002). Perceived performance is able to provide the researcher a full picture of the firm's performance as in the case of actual performance (Delaney \& Huselid, 1996). Albeit increased measurement error and potential self-report bias, perceived performance is widely used in business research. Perceived performance was chosen over actual performance due to difficulties in assessing assets values in emerging economies as managers are reluctant to reveal the true figures. SMEs are privately held firms where there is no financial data available for the public (Dollinger \& Golden, 1992). It is also common for SMEs to adopt various accounting methods to derive and record their salaries and expenses as well as inventory and depreciation values (Powell, 1992). Hence, objective financial measures might not be more accurate and more comparable across firms, than perceptual assessments (Delaney \& Huselid, 1996).

Each item in the FP scale requires respondents to benchmark their organizational performance against the average performance of their industry competitors. Sample items are "How would you compare the organization's performance over the past 3 years to that of other organizations that do the same kind of work? What about quality of products services, or programs?" (Perceived Organization Performance), and "Compared to other organizations that do the same kind of work, how would you compare the organization's performance over the last 3 years in terms of marketing?" (Perceived Market Performance).

\section{Sampling and Survey Procedures}

Quantitative approach was adopted in this research. A total of 113 self-administered questionnaires were collected from SMEs in Malaysia. The target participants were owner managers; so it is assumed that they were in the right capacity to respond to items on firms' financial performance (Olson \& Bosserman, 1984).

The reliability levels for entrepreneurial attitudes and firm performance are listed in Table 1 below. 
Table 1 . Reliability coefficients

\begin{tabular}{ll}
\hline Construct & Cronbach Alpha \\
\hline Entrepreneurial Attitudes & 0.953 \\
Achievement & 0.901 \\
Self-esteem & 0.845 \\
Personal control & 0.732 \\
Innovation & 0.822 \\
Opportunity recognition & 0.894 \\
Firm's performance & 0.857 \\
\hline
\end{tabular}

All the constructs were tested for the consistency reliability of the items within the constructs by using the cronbach alpha reliability analysis. The results indicated that cronbach alpha for all the constructs were well above 0.70 as recommended by Cavana et al. (2001). Cronbach alpha for the constructs ranged from the lowest of 0.732 (personal control) to highest 0.901 (achievement). In conclusion, the results showed that the scores of the cronbach alpha for all the constructs used in this study exceeded the preferable scores of 0.70 . This means that the measurement scales of the constructs were stable and consistent.

Simple linear regression was applied to determine the causal relationship between entrepreneurial attitude and firm performance. Results from Table 2 show that there are positive significant relationships between the five dimensions of entrepreneurial attitude and firm performance.

Table 2. Simple linear regression analysis with entrepreneurial attitude predicting firm's performance

\begin{tabular}{lllll}
\hline Construct & $\mathrm{R}$ & RSquare & $\mathrm{F}$ & Sig \\
\hline Entrepreneurial Attitudes & 0.429 & 0.184 & 25.008 & 0.000 \\
Achievement & 0.336 & 0.113 & 14.089 & 0.000 \\
Self-esteem & 0.410 & 0.168 & 22.410 & 0.000 \\
Personal control & 0.391 & 0.153 & 20.013 & 0.000 \\
Innovation & 0.467 & 0.219 & 31.042 & 0.000 \\
Opportunity recognition & 0.403 & 0.162 & 21.509 & 0.000 \\
\hline
\end{tabular}

\section{Discussions}

Table 2 reveals that the factor with the largest impact on firm performance is innovation ( $\mathrm{R}$ Square $=0.219$ ). According to Brown and Eisenhardt (1998), innovative firms are able to generate significant economic performance due to their capability in creating and introducing new products and technologies. These firms enjoy first-mover advantage where they are able to charge premium prices and thus obtain extraordinary profits (Zahra \& Covin, 1995). Using profits they obtained, they can easily control and dominate the distribution channels. Profits generated can also be used to develop and enhance brand recognition (Wiklund \& Shepherd, 2005).

Self-esteem is the factor with second largest impact on firm performance (R Square $=0.168$ ). According to Hogg and Cooper (2007), self-esteem refers to an individual perceived competency and self-confidence. Hence, individuals who are confident in their skills and abilities will be motivated to commit the necessary effort (Douglas \& Shepherd, 2000). This in turn leads to higher chances for high self-esteem individuals to succeed in their business ventures.

Opportunity recognition achieves an R Square of 0.162 (refer to table 2 above). According to McCline, Bhat and Baj (2000), opportunity recognition captures the intimate relationship between cognition and action. Individuals with high score of opportunity recognition manage to identify profit potential via the establishment of a new business or improvement of an existing business (Christensen \& Peterson, 1990). Hence, this unique ability of opportunity recognition will give entrepreneur an edge in gaining economic profits. 
Personal control $(\mathrm{R}$ Square $=0.153)$ is defined as the perception of control an individual has over his/her life and the subsequent reward derived from that behavior (Rotter, 1966). Individuals with high personal control tend to attribute their successes to internal factors (i.e. ability) than external (i.e. luck). When individuals believe they have the ability to control their destinies, they tend to have more confidence, commitment and determination in whatever they do (Weiner \& Kukla, 1970). This in turn enables the individuals to press on and eventually become successful in their businesses.

The factor created the smallest impact on firm performance was achievement $(\mathrm{R}$ Square $=0.113)$. Achievement reflects one's desire for appreciation and to be recognized. This desire to perform better will in turn motivate one to strive for success (McClelland, 1961). The individual that possesses this need is said to be inclined in exploratory efforts. This individual tends to possess greater self-satisfaction and readiness in facing challenges, which are needed to succeed in a business venture.

\section{Conclusions}

Attitude unlike demographics can be shaped through education. Efforts that encourage entrepreneurship should be carefully aligned in order to ensure a healthy supply of future entrepreneurs in the country. Educational efforts can help alter an individual's perception on self-employment, change the way they approach entrepreneurship, and their attitude towards it.

Not only the results of this study are applicable to SMEs but they are also applicable to multinational corporations. Boosting entrepreneurial attitude among their employees can instil innovativeness and motivate them to seek for business opportunities. All these will most likely translate into higher revenues and profits for the companies.

\section{References}

Ajzen, I. (1982). On behaving in accordance with one's attitudes'. In Consistency in social behavior: The Ontario symposium. Hillsdale: Lawrence Erlbaum Associates.

Ajzen, I., \& Fishbein, M. (2005). The influence of attitudes on behavior'. In D. Albarracín, B. T. Johnson, \& M. P. Zanna (Eds.), The handbook of attitudes. Mahwah: Lawrence Erlbaum Associates.

Ajzen, I., \& Madden, T. J. (1986). Prediction of goal-directed behavior: attitudes, intentions, and perceived behavioral control. Journal of Experimental Social Psychology, 22, 453-474. http://dx.doi.org/10.1016/0022-1031(86)90045-4

Allport, G. W. (1935). Attitudes, in Handbook of social psychology. Worcester: Clark University Press.

Brown, S. L., \& Eisenhardt, K. M. (1998). Competing on the edge. Boston: Harvard Business School Press.

Carland, J. W., Hoy, F., Boulton, W. R., \& Carland, J. C. (1984). Differentiating entrepreneurs from small business owners: a conceptualization. Academy of Management Review, 9(2), 354-359.

Cavana, R. Y. M., Delahaye, B. L., \& Sekaran, U. (2001). Applied business changing information environment (2nd ed.). New York: McGraw-Hill.

Christensen, P. S., \& Peterson, R. (1990). Opportunity identification: mapping the sources of new venture ideas, in Proceedings of 10th Annual Babson Entrepreneurship Research Conference, Aarhus University Institute of Management, Denmark.

Delaney, J. T., \& Huselid, M. A. (1996). The impact of human resource management practices on perceptions of organizational performance. Academy of Management Journal, 39(4), 949-969. http://dx.doi.org/10.2307/256718

Department of Statistics Malaysia. (2006). SME Annual Report 2006. Malaysia.

Din, M. S., Hoe, C. H., Hashim, N., Ooi, Y. K., Ahmad, S., Bakar, H., ... Md Hussain, M. N. (2005). Asas Keusahawanan. Kuala Lumpur: Prentice Hall.

Dollinger, M. J., \& Golden, P. A. (1992). Interorganizational and collective strategies in small firms: environmental effects and performance. Journal of Management, 18, 695-715. http://dx.doi.org/10.1177/014920639201800406

Douglas, E. I., \& Shepherd, D. A. (2000). Entrepreneurship as a utility maximizing response. Journal of Business Venturing, 15(3), 231-251. http://dx.doi.org/10.1016/S0883-9026(98)00008-1

Drucker, P. F. (1970). Entrepreneurship in business enterprise. Journal of Business Policy, 1, 10-11.

Drucker, P. F. (1985). Innovation and entrepreneurship: Practice and principles. New York: Harper and Row. 
Epstein, S. (1984). A procedural note on the measurement of broad dispositions. Journal of Personality, 52, 318-325. http://dx.doi.org/10.1111/j.1467-6494.1984.tb00354.x

Gasse, Y. (1985). A strategy for the promotion and identification of potential entrepreneurs at the secondary school level. In Frontiers of entrepreneurship research. Wellesley: Babson College

Greenberger, D. B., \& Sexton, D. L. (1987). Leadership and entrepreneurship: new directions for venture initiation and success'. In New ventures: Creation, Development, Support: The Proceedings of the Second Annual Conference of the United States Association for Small Business and Entrepreneurship. Marietta: Kennesaw College.

Hair, J. F. J., Money, A. H., Samouel, P., \& Page, M. (2007). Research methods for business. West Sussex: John Wiley \& Sons.

Hogg, M. A., \& Cooper, J. (2007). Sage handbook of social psychology. London: Sage Publications.

Huefner, J. C., Hunt, H. K., \& Robinson, P. B. (1996). A comparison of four scales predicting entrepreneurship. Academy of Entrepreneurship Journal, 1(2), 56-80.

Linan, F., Rodriguez-Cohard, J. C., \& Rueda-Cantuche, J. M. (2005). Factors affecting entrepreneurial intention levels. In $45^{\text {th }}$ Congress of the European Regional Science Association, Amsterdam.

Lindsay, N. J., Jordaan, A., \& Lindsay, W. A. (2005). Values and entrepreneurial attitude as predictors of nascent entrepreneur intentions'. In Proceedings of the 50th International Council for Small Business Conference, Small Business Advancement National Center - University of Central Arkansas, Washington DC.

Lumpkin, G. T., \& Dess, G. G. (1996). Clarifying the entrepreneurial orientation construct and linking it to performance. Academy of Management Review, 21(1), 135-172.

McClelland, D. C. (1961). The achieving society. Reinhold: Princeton.

McCline, R. L., Bhat, S., \& Baj, P. (2000). Opportunity recognition: an exploratory investigation of a component of the entrepreneurial process in the context of the health care industry. Entrepreneurship: Theory \& Practice, 25(2), 81-94.

Olson, P. D., \& Bosserman, D. A. (1984). Attributes of the entrepreneurial type. Business Horizons, 53-56. http://dx.doi.org/10.1016/0007-6813(84)90027-2

Powell, T. C. (1992, May-June). Organizational alignment as competitive advantage. Strategic Management Journal, 13(2), 119-134. http://dx.doi.org/10.1002/smj.4250130204

Robinson, P. B., Stimpson, D. V., Huefner, J. C., \& Hunt, H. K. (1991). An attitude approach to the prediction of entrepreneurship. Entrepreneurship Theory and Practice, 15(4), 13-31.

Rotter, J. B. (1966). Generalized expectancies for internal versus external control of reinforcements. Psychological Monographs, 80(1), 1-28. http://dx.doi.org/10.1037/h0092976

Schumpeter, J. (1976). Capitalism, socialism and democracy. New York: Harper and Row.

Schumpeter, J. A. (1983). The theory of economic development: an inquiry into profits, capital, credit, interest, and the business cycle. New Brunswick: Transaction Publishers.

Strauss, J. P. (2005). Multi-source perspectives of self-esteem, performance ratings, and source agreement. Journal of Managerial Psychology, 20(6), 464-482. http://dx.doi.org/10.1108/02683940510615424

Venkataraman, S. (1997). The distinctive domain of entrepreneurship research: an editor's perspective. In J. Katz, \& J. Brockhaus (Eds.), Entrepreneurship, firm emergence, and growth. Greenwich: JAI Press.

Ward, S., Pearson, C., \& Entrekin, L. (2002). Chinese cultural values and the Asian meltdown. International Journal of Social Econonmics, 29(3), 205-217. http://dx.doi.org/10.1108/03068290210417098

Weiner, B., \& Kukla, A. (1970). An attributional analysis of achievement motivation. Journal of Personality and Social Psychology, 15(1), 1-20. http://dx.doi.org/10.1037/h0029211

Wiklund, J., \& Shepherd, D. (2005). Entrepreneurial orientation and small business performance: a configurational approach. Journal of Business Venturing, 20(1), 71-91. http://dx.doi.org/10.1016/j.jbusvent.2004.01.001

Zahra, S., \& Covin, J. (1995). Contextual influence on the corporate entrepreneurship - performance relationship: a longitudinal analysis. Journal of Business Venturing, 10(1), 43-58. http://dx.doi.org/10.1016/0883-9026(94)00004-E 